\title{
IDENTIFIKASI MENTAL COMPUTATION SISWA DISLEKSIA DALAM MELAKUKAN OPERASI PENJUMLAHAN DAN PENGURANGAN BILANGAN BULAT
}

\author{
Lisanul Uswah Sadieda', Agustin Eka Cahyani ${ }^{2}$ \\ ${ }^{1,2}$ UIN Sunan Ampel Surabaya, Jl. A. Yani 117 Surabaya
}

\begin{abstract}
To describe mental computation strategies of the dyslexic student in performing the addition and subtraction of 1-digit and 2-digit integer. Mental computation is a process of doing arithmetic calculations without using other tools. This strategy will help dyslexic students find more accurate and flexible solution while solving the arithmetic problem because it can minimize their weaknesses in terms of reading and writing. This research uses the qualitative approach. Data were collected by using a task-based interview for two dyslexic students. The results of this study indicate that dyslexic students use the spin-around strategy to solve the addition for the 1digit number and the working from the right and from the left strategies to solve the addition for the 2-digit number. Meanwhile, to solve the subtraction problem, dyslexic students use think addition and counting back strategies for the 1-digit number and Working from The Right strategy for the 2-digit number.
\end{abstract}

Keywords: Mental computation; Dyslexia; Addition; Subtraction.

\section{PENDAHULUAN}

Operasi hitung bilangan adalah kompetensi dasar yang harus dikuasai siswa pada setiap jenjang pendidikan. Siswa wajib memiliki keterampilan melakukan operasi hitung (penjumlahan, pengurangan, perkalian dan pembagian) pada bilangan bulat, rasional dan real serta menggunakannya untuk menyelesaikan masalah yang semakin meningkat di setiap jenjangnya. Hal ini tertuang dalam Permendikbud Nomor 24 Tahun 2016 tentang Kompetensi Inti dan Kompetensi Dasar Pelajaran pada Kurikulum 2013 Pendidikan Dasar dan Pendidikan Menengah (Kemdikbud, 2016). Keterampilan operasi hitung bilangan ini juga menjadi fokus pembahasan di beberapa negara terutama perhitungan dengan menggunakan strategi mental computation.

Menurut Sowder, mental computation adalah aktivitas yang dilakukan dalam perhitungan aritmetika tanpa menggunakan bantuan dari perangkat eksternal seperti pensil dan kertas serta kalkulator (Hartnett, 2007). Strategi ini sebenarnya digunakan dalam melakukan proses perhitungan sehari-hari yang seringkali tidak memerlukan alat 
bantu perhitungan maupun pada saat perhitungan yang ditekankan pada kecepatan. McIntosh (2016) menyatakan bahwa dalam kehidupan sehari-hari orang dewasa menggunakan strategi mental computation lebih dari $75 \%$ sedangkan perhitungan tertulis dan kalkulator digunakan kurang dari 15\%. Selain itu strategi ini bukan hanya strategi yang berfokus pada kecepatan dan keakuratan seseorang dalam memanggil kembali fakta-fakta terkait bilangan yang hanya mengandalkan ingatan. Rogers (2016) menjelaskan bahwa mental computation mendasarkan pada pendekatan konstruktivis yang dapat mengembangkan pemahaman dan kemampuan metakognisi. Oleh karena itu, semestinya pembelajaran di sekolah memberikan porsi yang lebih banyak untuk melatih ketrampilan siswa dalam menggunakan strategi ini.

Namun, Herman dalam penelitiannya menemukan mayoritas siswa kelas 7 mengalami kesulitan menghitung $15 \times 6$ dalam kepala dan cenderung menggunakan algoritma tulis (menggunakan alat tulis). Padahal pada dasarnya keterampilan mental computation anak berkembang terlebih dahulu sebelum keterampilan menghitung menggunakan algoritma tulis karena lebih dekat dengan karakter alami anak (Rogers, 2016). Hal ini dapat terjadi karena ketika perhitungan secara mental ini berjalan secara natural, guru seringkali mengganggu proses ini dengan meminta anak untuk menggunakan algoritma tulis. Penggunaan algoritma tulis di awal pembelajaran akan mengakibatkan anak-anak tidak menggunakan strategi berpikir intuitif tetapi hanya sekedar mengikuti langkah sistematis dari algoritma.

Kemampuan berpikir intuitif terkait bilangan yang rendah akan menyulitkan siswa dalam memahami bilangan dan operasinya. Dalam NCTM (2015) disebutkan bahwa kemampuan intuisi terkait besaran bilangan dan kombinasinya serta kemampuan mengoperasikan bilangan secara fleksibel untuk menyelesaikan suatu masalah dikenal dengan number sense (kepekaan terhadap bilangan). Kemampuan ini salah satunya meliputi fleksibilitas dalam proses menghitung tanpa alat bantu (mental computation). Oleh karena itu mental computation membantu siswa dalam mengembangkan number sense karena dengan mental computation akan membuat siswa berpikir (Reys and Barger dalam Tsao, 2014). Siswa ditekankan untuk tidak menggunakan algoritma tulis yang terkesan kaku dan menghambat siswa untuk menemukan sendiri pemikiran yang terkait dengan bilangan.

Penjelasan tersebut menunjukkan bahwa penggunaan strategi mental computation 
dalam menyelesaikan permasalahan matematika akan membantu mengembangkan akurasi, efisiensi dan fleksibilitas solusi yang ditemukan. Setiap individu dapat memiliki strategi mental computation yang berbeda dalam menemukan solusi dari suatu masalah. Hal ini sesuai dengan hasil penelitian dari Ghazali, dkk (2010) menunjukkan bahwa strategi mental computation yang digunakan siswa tingkat 1,2 dan 3 dalam menyelesaikan operasi penjumlahan dan pengurangan tidaklah sama. Pada operasi penjumlahan satu digit bilangan, siswa mayoritas menggunakan strategi Counting on from first number sedangkan untuk penjumlahan dua digit menggunakan Separation right to left dan Wholistic-Compensation. Pada operasi pengurangan, siswa menggunakan Bridging through ten, Doubles fact (think addition), Doubles fact (think multiplication) dan Separation left to right.

Dalam modulnya yang berjudul Mental computation: A strategies approach, McIntosh (2004a) dan McIntosh (2004b) juga menyebutkan beberapa strategi mental computation yang digunakan oleh siswa ketika melakukan perhitungan untuk operasi penjumlahan dan pengurangan. Untuk operasi penjumlahan antara lain menggunakan strategi Counting On, Spin-Arrounds (commutativity), Doubles/Near Doubles, Bridging Ten/Multiples of Ten, Adding Parts of The Second Number, dan Working from The Left/ Right. Sedangkan untuk operasi pengurangan antara lain menggunakan strategi Think Addition (Inverse), Counting Back, Doubles/Near Doubles, Bridging Multiples of Ten dan Subtracting Parts of The Second Number.

Perbedaan pemilihan strategi tersebut dapat terjadi karena perbedaan proses berpikir dan belajar dari setiap individu. Proses belajar pada semua individu tidaklah selalu sama. Beberapa individu mengalami kemudahan dan tidak sedikit pula individu yang mengalami kesulitan. National Institute of Health, USA mendefinisikan kesulitan belajar sebagai hambatan/gangguan belajar pada anak dan remaja yang ditandai oleh adanya kesenjangan yang signifikan antara taraf intelegensia dan kemampuan akademik yang seharusnya dicapai (Idris, 2017). Terdapat beberapa jenis kesulitan belajar. Siswa yang mengalami kesulitan belajar akademik dapat terlihat ketika siswa tidak dapat menampilkan salah satu atau beberapa kemampuan akademik seperti membaca, menulis dan berhitung. Kesulitan belajar yang lebih sulit untuk dideteksi adalah kesulitan belajar yang terkait dengan perkembangan. Kesulitan belajar ini ditandai dengan penguasaan keterampilan prasyarat yang rendah, yaitu keterampilan yang harus dikuasai terlebih 
dahulu agar dapat menguasai bentuk keterampilan berikutnya.

Penelitian ini akan membatasi permasalahan mengenai learning disabilities. Learning disabilities merupakan suatu gangguan yang menyebabkan seseorang mengalami ketidakmampuan belajar atau menghindari belajar sehingga hasil belajar di bawah potensi intelektualnya.

Kesulitan belajar kemungkinan disebabkan oleh gangguan di dalam saraf pusat otak atau gangguan nuerobiologis yang dapat menimbulkan keterlambatan kematangan kognitif sehingga mengalami kesulitan pada salah satu kemampuan belajar seperti kesulitan membaca, bicara, menulis, pemahaman, dan berhitung. Ketidakmampuan belajar membaca bisa juga disebut disleksia. Menurut Hornsby, disleksia tidak hanya kesulitan belajar membaca, tapi juga menulis, karena mengingat ada keterkaitan diantara keduanya (Nirmalasari, 2013). Selanjutnya Grainger menyebutkan bahwa siswa didiagnosis menderita disleksia ketika kelemahan dalam membaca tidak disebabkan oleh hambatan intelektual, sensori, dan budaya melainkan diduga disebabkan oleh fungsi otak yang minimal (Nirmalasari, 2013).

Siswa yang mengalami learning disabilities, termasuk siswa disleksia, pada umumnya memiliki potensi IQ yang normal bahkan di atas rata-rata. Hanya saja karena secara psikologi mempunyai kebutuhan khusus dalam proses belajar, sebagian pendidik maupun masyarakat banyak yang menganggap sebagai siswa yang bodoh. Hal tersebut diperkuat oleh pendapat Hargreaves (Chotimah, 2013), "People with LDs have average to above average intelligence yet they have very specific impairments in one or more of the pyschological processes related to learning. These processes may include: 1) language processing; 2) visual-spatial processing; 3) visual-motor processing; 4) phonological processing; 5) processing speed; 6) working memory; 7) executive function".

Sejalan dengan pendapat Hargreaves, World Federation of Neurology mengungkapkan bahwa siswa yang mengidap disleksia mengalami kesulitan dalam membaca walaupun instruksinya bersifat umum, akan tetapi memiliki intelegensi dan kesempatan sosial yang cukup baik (Putri, 2017). Dalam bidang matematika atau berhitung, beberapa peneliti menemukan bahwa siswa disleksia memiliki kinerja matematika yang tinggi. Seperti yang dikemukakan oleh Guszak, Ekwall \& Shanker bahwa kinerja matematika siswa disleksia lebih tinggi daripada kinerja membaca 
(Istijani, 2013). Hal tersebut juga diperkuat oleh penelitian Steeves yang melaporkan bahwa banyak anak disleksia yang jenius dibidang matematika, sedangkan Joffe melaporkan bahwa 10\% anak disleksia menunjukkan prestasi yang sangat baik di bidang matematika (Dewi, 2010).

Sejauh ini penelitian terdahulu hanya menjelaskan bahwa sekalipun memiliki kekurangan dalam hal membaca, siswa disleksia memiliki prestasi yang baik dalam bidang matematika. Namun belum ada penelitian yang membahas secara spesifik tentang kemampuan siswa disleksia dalam melakukan operasi hitung bilangan terutama dengan menggunakan strategi mental computation. Padahal hal ini perlu untuk digali lebih dalam mengingat keterampilan operasi hitung bilangan adalah kompetensi dasar yang wajib dikuasai siswa termasuk siswa disleksia dan keterampilan ini akan berkembang dengan baik jika siswa terampil dalam mengaplikasikan strategi mental computation. Karena kelemahan siswa disleksia dalam membaca dan menuliskan jawaban akan terminimalisir dengan strategi mental computation yang tidak memerlukan alat bantu seperti kertas-pensil dalam perhitungannya. Oleh karena itu penelitian ini bertujuan mendeskripsikan mental computation strategies siswa disleksia untuk melakukan operasi hitung penjumlahan dan pengurangan bilangan bulat.

Hasil penelitian ini diharapkan dapat bermanfaat sebagai informasi awal mengenai kemampuan dan macam-macam strategi mental computation yang dikuasai oleh siswa disleksia. Selain dapat dijadikan feedback untuk menyempurnakan tindakan guru matematika dalam mengenalkan dan membiasakan penggunaan strategi mental computation pada siswa disleksia, juga dapat dijadikan bahan pertimbangan dalam pengembangan program pengajaran matematika di sekolah luar biasa maupun sekolah inklusi.

\section{METODE PENELITIAN}

Sesuai dengan tujuan penelitian yaitu mendeskripsikan strategi mental computation siswa disleksia dalam melakukan operasi hitung (penjumlahan dan pengurangan) bilangan bulat, maka pada penelitian ini digunakan pendekatan kualitatif deskriptif. Penelitian ini dilaksanakan pada bulan Juli sampai dengan Agustus 2016 dan bertempat di SLB Bina Bangsa Ngelom Sepanjang.

Dalam penelitian ini dipilih dua orang subjek (S1 dan S2) dari kelas tuna grahita 
sedang. Pertimbangannya mereka memiliki kemampuan matematika lebih tinggi dan mudah berinteraksi dibandingkan siswa disleksia lain. S1 merupakan siswa yang aktif dalam kegiatan olahraga dan seni. Namun, seperti siswa disleksia lain dia mengalami kesulitan dalam membaca dan menulis serta berbicara dengan tutur kata yang kurang teratur. Pada saat diminta membaca, S1 membaca secara lamban kata per kata, sering menebak dan mengulangi kata-kata, kesulitan dalam konsentrasi juga kesulitan menyimpan informasi dalam memori. Sedangkan S2 merupakan pribadi yang lebih emosional dan sering mengalami kejang. Seperti halnya S1, dia membaca secara lamban kata per kata, sering membolak-balik huruf atau kata-kata, sering menebak dan mengulangi kata-kata serta kesulitan menyimpan informasi dalam memori.

Untuk mendapatkan data tentang strategi mental computation yang digunakan subjek maka digunakan metode wawancara berbasis tugas. Metode ini diawali dengan cara memberi tugas berupa enam soal jawaban singkat terkait operasi hitung pada penjumlahan dan pengurangan bilangan bulat pada nilai tempat satuan dan puluhan. Soal yang diselesaikan adalah sebagai berikut: (1) $1+8$; (2) $27+12$; (3) 43+23; (4) 8-5; (5) 59-25; dan (6). 85-71. Setelah itu subjek langsung diwawancarai mengenai strategi yang digunakan untuk menyelesaikan soal yang telah diberikan. Wawancara ini dilakukan secara mendalam sampai peneliti mendapatkan data tentang strategi yang digunakan subjek secara jelas. Data yang didapat kemudian diuji keabsahannya dengan menggunakan triangulasi waktu. Pada tahap ini, data yang diperoleh dari pengambilan data pertama dibandingkan dengan data kedua dan ketiga. Soal nomor 1 dan 4 digunakan dalam pengambilan data pertama, soal nomor 2 dan 5 untuk pengambilan data kedua dan soal nomor 3 dan 6 untuk pengambilan data ketiga.

Data yang telah terkumpul selanjutnya dianalisis dengan langkah-langkah sebagai berikut: 1) Mereduksi data yang dilakukan dengan memilah data yang sesuai untuk menjawab pertanyaan penelitian kemudian mentranskrip hasil wawancara yang telah diberi kode berbeda untuk setiap subjeknya dengan memperhatikan beberapa catatan pada saat wawancara; 2) Memaparkan data hasil tes dan wawancara kedua subjek berdasarkan operasi perhitungan pada pengambilan data pertama, kedua, dan ketiga; 3) Pengambilan kesimpulan dilakukan dengan cara melihat semua strategi mental computation yang digunakan oleh setiap subjek pada setiap operasi dalam menyelesaikan soal matematika yang diberikan. 
Berikut ini adalah beberapa strategi mental computation berdasarkan pendapat McIntosh yang digunakan pada operasi hitung (penjumlahan dan pengurangan) pada bilangan bulat dalam penelitian ini:

Tabel 1. Strategi Mental Computation

\begin{tabular}{|c|c|}
\hline Strategi Mental Computation & Contoh pada Penjumlahan \\
\hline Spin-Arrounds (komutatif) & $2+5=5+2=7$ \\
\hline Counting On (menghitung maju) & $6+3 ; ;^{\prime} 6,7,8,9^{\prime}$ \\
\hline Doubles (ganda) & $5+5=10$ \\
\hline Near Doubles (dekat dengan ganda) & $5+7=(5+5)+2=10+2=12$ \\
\hline $\begin{array}{l}\text { Bridging Ten /Bridging Multiple of Ten } \\
\text { (menghubungkan dengan 10) }\end{array}$ & $\begin{array}{l}8+6=(8+2)+4=10+4=14 \\
47+8=(47+3)+5=50+5=55\end{array}$ \\
\hline $\begin{array}{l}\text { Adding Parts of the Second Number } \\
\text { (menambah dengan sebagian bilangan kedua) }\end{array}$ & $\begin{array}{l}29+26=29+(20+6)=(29+20)+6=49+ \\
6=55\end{array}$ \\
\hline $\begin{array}{l}\text { Working from the Left (menjumlahkan dari } \\
\text { kiri) }\end{array}$ & $29+26 ; 20+20=40,9+6=15 ; 40+15=55$ \\
\hline \multirow{2}{*}{$\begin{array}{l}\text { Working from the Right (menjumlahkan dari } \\
\text { kanan) }\end{array}$} & $29+26 ; 9+6=15,20+20=40 ; 15+40=55$ \\
\hline & Contoh pada Pengurangan \\
\hline Counting Back (menghitung $\mathrm{m}$ & $7-5 ; \cdot 7,6,5$, \\
\hline Think Addition (menjadikan penjumlahan) & $9-4 ; 4+\ldots=9 ; 4+5=9 ; 9-4=5$ \\
\hline $\begin{array}{l}\text { Bridging Multiples of Ten (menghubungkan } \\
\text { dengan 10) }\end{array}$ & $35-8=35-5-3=30-3=27$ \\
\hline $\begin{array}{l}\text { Substracting Parts of The Second Number } \\
\text { (mengurangkan dengan sebagian bilangan } \\
\text { kedua) }\end{array}$ & $\begin{array}{l}48-17=48-(10+7)=(48-10)-7=38-7 \\
=31\end{array}$ \\
\hline
\end{tabular}

\section{HASIL DAN PEMBAHASAN}

Hasil tes dan wawancara mengenai penyelesaian soal menggunakan strategi mental computation, kedua subjek pada saat menyelesaikan soal penjumlahan pengambilan data pertama, kedua dan ketiga dapat dilihat pada Tabel 2.

Tabel 2. Strategi Mental Computation pada Operasi Penjumlahan

\begin{tabular}{ccc}
\hline \multirow{2}{*}{ Pengambilan Data } & \multicolumn{2}{c}{ Strategi Mental Computation } \\
\cline { 2 - 3 } & Subjek S1 & Subjek S2 \\
\hline Pertama & Spin-arounds (komutatif) & Spin-arounds (komutatif) \\
Kedua & Working from The Right & Working from The Left \\
& (menjumlahkan dari kanan) & (menjumlahkan dari kiri) \\
Ketiga & Working from The Right & Working from The \\
(menjumlahkan dari kanan) & Left(menjumlahkan dari kiri) \\
\hline
\end{tabular}

Berdasarkan hasil pengambilan data pertama tampak bahwa kedua subjek menggunakan strategi spin-arounds dalam menyelesaikan penjumlahan pada bilangan bulat satuan. Untuk menyelesaikan soal " $1+8$ ", mereka mengoperasikan bilangan yang besar terlebih dahulu sehingga perhitungannya menjadi " $8+1$ ". Hal ini dilakukan 
karena menurut mereka cara tersebut paling mudah dan cepat dengan hasil operasi yang sama.

Akan tetapi, perbedaan penggunaan strategi tampak pada penyelesaian soal operasi penjumlahan bilangan bulat puluhan yang terlihat pada hasil pengambilan data kedua dan ketiga. S1 cenderung menggunakan strategi working from the right sedangkan S2 cenderung menggunakan strategi working from the left. Pada awalnya S1 menyelesaikan soal " $27+12$ " dengan cara membayangkan perhitungan bersusun secara mental. Jadi dia memulai dengan menjumlahkan bilangan bernilai satuan yang berada di sebelah kanan dengan bilangan bernilai puluhan di sebelah kirinya, kemudian menjumlahkan hasilnya. Berikut adalah cuplikan wawancara dengan subjek S1:

$P$ : Coba ceritakan bagaimana kamu menghitungnya sampai ketemu jawaban tiga puluh sembilan?

$S_{I}$ : Iya dihitung dari belakang Seperti dihitung susun

$P$ : Bagaimana?

$S_{1}$ : Tujuh ditambah dua hasilnya sembilan. Terus dua ditambah satu itu tiga.

$P$ : Tadi kenapa kok jawabannya tiga puluh sembilan?

$S_{I}$ : Yang berapa tadi...Sembilan ditambah tiga puluh

$P$ : Kenapa mengunakan cara itu?

$S_{1}$ : Diajarinnya gitu

Jika diilustrasikan proses perhitungan menggunakan strategi working from the right yang dilakukan S1 adalah sebagai berikut:

$\begin{array}{ll}27+12 & = \\ (7+2)+(20+10) & = \\ 9+30 & =39\end{array}$

Berdasarkan cuplikan wawancara di atas tampak bahwa strategi yang dipilih oleh S1 ini dipengaruhi oleh teknik penjumlahan bersusun yang diajarkan oleh guru untuk menyelesaikan soal penjumlahan seperti ini. Sehingga secara otomatis dia menyusun dua bilangan itu secara mental kemudian melakukan operasinya seperti kalau menggunakan algoritma tulis.

S2 menggunakan cara yang serupa dengan S1. Namun, memulai perhitungan dari bilangan bernilai puluhan di sebelah kiri kemudian dijumlahkan dengan bilangan bernilai satuan di sebelah kanan.

$P$ : Coba ceritakan bagaimana kamu menghitungnya?

$S_{2}:$ Ya ditambah satu-satu

$P$ : Ditambah satu-satu bagaimana?

$S_{2}:$ Empat ditambah dua terus tiga ditambah tiga

$P$ : Terus bagaimana lagi?

$S_{2}$ : Empat ditambah dua sama dengan enam. Tiga ditambah tiga sama dengan enam. 
Jadi hasilnya enam puluh enam

$P$ : Mengapa demikian?

$S_{2}:$ Ya hasilnya tadi ditambah enam puluh ditambah enam kan enampuluh enam

$P$ : Apakah menurutmu cara tersebut yang paling cepat untuk menghitung soal seperti itu?

$S_{2}:$ Iya

$P$ : Kenapa menghitungnya menggunakan cara itu?

$S_{2}$ : Soalnya lebih mudah kalau yang besar dulu

Jika diilustrasikan proses perhitungan menggunakan strategi working from the left yang dilakukan $\mathrm{S} 2$ adalah sebagai berikut:

$43+23=$

$(40+20)+(3+3)=$

$60+6=66$

Pemilihan strategi yang memulai perhitungan dari bilangan yang lebih besar memang memudahkan bagi S2, seperti tampak pada percakapan terakhir di atas. Hal ini sesuai dengan alasan yang dia ungkapkan ketika menyelesaikan soal penjumlahan bilangan bulat satuan pada pengambilan data pertama.

Hasil tes dan wawancara mengenai penyelesaian soal menggunakan strategi mental computation, kedua subjek pada saat menyelesaikan soal pengurangan pada pengambilan data pertama, kedua dan ketiga dapat dilihat pada Tabel 3.

Tabel 3. Strategi Mental Computation pada Operasi Pengurangan

\begin{tabular}{ccc}
\hline \multirow{2}{*}{ Pengambilan Data } & \multicolumn{2}{c}{ Strategi Mental Computation } \\
\cline { 2 - 3 } Pertama & Think Addition (Menjadikan & Subjek S2 \\
& $\begin{array}{c}\text { Penjumlahan) } \\
\text { Kedua }\end{array}$ & $\begin{array}{c}\text { Counting Back } \\
\text { digung from The Right, namun pada operasi } \\
\text { pengurangan }\end{array}$ \\
Ketiga & $\begin{array}{c}\text { Working from The Right, namun } \\
\text { digunakan pada operasi } \\
\text { porking from The Left, namun } \\
\text { digunakan pada operasi } \\
\text { pengurangan }\end{array}$ & $\begin{array}{c}\text { Working from The Left, namun } \\
\text { digunakan pada operasi } \\
\text { pengurangan }\end{array}$ \\
\hline
\end{tabular}

Tabel 3 di atas menunjukkan adanya perbedaan strategi yang digunakan kedua subjek pada saat menyelesaikan soal terkait operasi pengurangan pada bilangan bulat satuan pada pengambilan data pertama. S1 menggunakan strategi think addition sedangkan S2 menggunakan counting back. Think addition merupakan strategi penyelesaian soal operasi pengurangan dengan cara mengubah soal pengurangan menjadi soal penjumlahan. Berikut merupakan cuplikan wawancara dari S1: 
$P$ : Coba ceritakan bagaimana kamu menghitungnya sampai ketemu jawaban tiga?

$S_{1}$ : Ditambah berapa sama dengan delapan

$P$ : Iya bagaimana?

$S_{1}:$ Ya lima ditambah tiga kan delapan

$P$ : Kenapa kok bisa begitu?

$S_{1}$ : Dulu diajarinnya begitu

Cuplikan wawancara tersebut menunjukkan bahwa untuk menjawab "8 - 5" siswa menggunakan strategi think addition dengan cara mengubah " $8-5$ " menjadi " $5+\ldots$. 8" sehingga menghasilkan jawaban yang tepat yaitu "3".

Lain halnya dengan S2 yang menggunakan strategi counting back yaitu strategi yang menyelesaikan soal operasi pengurangan dengan cara menghitung mundur sebanyak bilangan kedua dari bilangan pertama atau sebaliknya. Hal ini dapat dilihat pada cuplikan wawancara berikut:

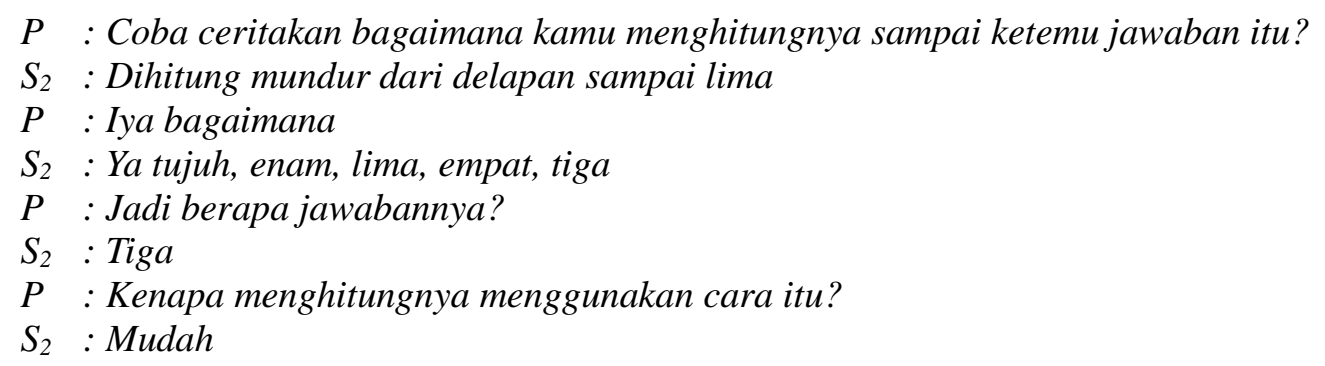

Jika diilustrasikan hasilnya ialah sebagai berikut:

$8-5=$



Ilustrasi di atas menunjukkan bahwa S2 menghitung mundur sebanyak lima langkah dari bilangan pertama sehingga menghasilkan jawaban yang tepat yaitu "3".

Berbeda dengan pengambilan data pertama, pengambilan data kedua dan ketiga menunjukkan strategi yang sama antara S1 dengan S2. Pada pengambilan data kedua, S1 dan S2 menggunakan strategi working from the right. Sedangkan pada pengambilan data ketiga, keduanya sama-sama menggunakan strategi working from the left. Berikut ini merupakan cuplikan wawancara pada S1 pada pengambilan data kedua:

$P$ : Coba ceritakan bagaimana kamu menghitungnya sampai ketemu jawaban tiga puluh empat?

$S_{1}:$ Dikurangi dari yang belakang

$P$ : Iya bagaimana?

$S_{1}$ : Sembilan dikurangi lima itu empat. Terus lima dikurangi dua kan tiga.

$P$ : Terus bagaimana lagi?

$S_{1}:$ Ya sudah berarti tiga puluh empat 
$P$ : Kenapa menghitungnya menggunakan cara itu?

$S_{1}$ : Ya kan mudah seperti disusun

S1 dalam menyelesaikan soal "59 - 25", mengoperasikan bilangan yang berada di sebelah kanan terlebih dahulu kemudian baru bilangan yang disebelah kiri. Jika diilustrasikan akan tampak sebagai berikut:

$$
\begin{array}{ll}
59-25 & = \\
(9-5)+(50-20) & = \\
4+30 & =34
\end{array}
$$

Sama halnya dengan penyelesaian soal penjumlahan pada bilangan bulat puluhan, S1 memilih strategi ini karena otomatis pemikirannya merujuk pada strategi yang sering digunakan di sekolah, yaitu pengurangan dengan cara bersusun seperti terlihat pada akhir cuplikan wawancara di atas.

Pada pengambilan data ketiga, keduanya menggunakan cara yang berbeda dengan pengambilan data kedua meskipun soal yang diberikan memiliki jenis yang sama, yaitu soal pengurangan pada bilangan bulat puluhan. Kedua subjek menggunakan strategi working from the left yaitu mengoperasikan bilangan yang berada di sebelah kiri atau bilangan bernilai puluhan terlebih dahulu kemudian dilanjutkan dengan bilangan di sebelah kanan atau yang bernilai satuan seperti tampak pada cuplikan wawancara berikut:

\footnotetext{
$P$ : Coba ceritakan bagaimana kamu menghitungnya sampai ketemu jawaban itu?

$S_{2}:$ Delapan dikurangi tujuh kan satu. Terus lima dikurangi satu kan empat

$P$ : Berapa hasilnya?

$S_{2}:$ Empatbelas

$P:$ Apakah menurutmu cara tersebut yang paling cepat untuk menghitung soal seperti itu?

$S:$ Iya bisa dari belakang juga
}

Cara ini sebenarnya tidak lazim digunakan untuk operasi pengurangan. Namun jika dilihat pada cuplikan wawancara bagian akhir di atas, S2 mengatakan "Iya bisa dari belakang juga" yang mengindikasikan penggunaan strategi working from the rightsebagai alternatif lain. Berdasarkan hal tersebut maka dapat disimpulkan bahwa dalam menyelesaikan soal pengurangan bilangan bulat puluhan kedua subjek cenderung menggunakan strategi working from the right.

Hasil penelitian di atas menunjukkan bahwa ketika siswa disleksia diminta untuk menghitung secara mental, mereka cenderung melakukan operasi penjumlahan dan 
pengurangan dengan cara membayangkan algoritma tulis yang sering digunakan di sekolah dalam kepala. Strategi seperti ini memang sering digunakan oleh siswa ketika diminta untuk menghitung tanpa alat bantu kertas. Berdasarkan penelitian yang dilakukan Herman (2016) disebutkan bahwa dari semua soal penjumlahan dan pengurangan yang ditanyakan terhadap subjek, diketahui bahwa 92,6\% tergolong dalam strategi pensil-dan-kertas dalam kepala. Sedangan Ghazali, dkk (2010) menunjukkan bahwa mayoritas subjek cenderung menggunakan strategi pensil-dan-kertas dalam kepala untuk menghitung penjumlahan dari dua atau tiga digit bilangan.

Penelitian ini juga menunjukkan bahwa siswa tidak mengalami kesulitan yang berarti dalam melakukan operasi penjumlahan dan pengurangan secara mental pada bilangan bulat satuan maupun puluhan. Mereka berdua dapat menjawab dengan cepat dan memberi alasan yang logis terhadap jawaban mereka. Kedua subjek juga memiliki pengetahuan yang baik terkait sifat penjumlahan bilangan bulat yaitu sifat komutatif. Pada saat menyelesaikan soal " $1+8$ " dan subjek menyelesaikan dengan cara " $8+1$ ", peneliti bertanya "Kenapa kok delapan ditambah satu? Kan tadi soalnya satu ditambah delapan? kemudian subjek menjawab "iya kan sama aja jawabannya". Hal ini menunjukkan bahwa dia mengetahui bahwa " $1+8$ " dan " $8+1$ " memiliki nilai yang sama. Hal ini sesuai dengan pendapat Guszak yang menyatakan bahwa kinerja matematika siswa disleksia lebih tinggi daripada kinerja membaca (Istijani, 2013). Begitu juga pendapat Ekwall \& Shanker yang menyatakan bahwa prestasi belajar siswa disleksia dalam berhitung lebih tinggi daripada dalam membaca dan mengeja (Istijani, 2013).

\section{SIMPULAN DAN SARAN}

Siswa disleksia dalam menyelesaikan soal operasi penjumlahan pada bilangan bulat satuan menggunakan strategi Spin-Arounds (komutatif). Sedangkan untuk operasi penjumlahan pada bilangan bulat puluhan menggunakan strategi Working from The Right dan Working from The Left. Kemudian untuk menyelesaikan soal pengurangan, siswa disleksia menggunakan strategi Think Addition (menjadikan penjumlahan) dan Counting Back untuk operasi pengurangan pada bilangan bulat satuan dan untuk operasi pengurangan pada bilangan bulat puluhan menggunakan strategi Working from The Right. 
Penggunaan soal pada operasi hitung (pengurangan dan penjumlahan) yang lebih bervariasi sangat disarankan bagi peneliti selanjutnya agar dapat mengeksplor strategi mental computation siswa lebih dalam lagi.

\section{DAFTAR RUJUKAN}

Chotimah, C. (2013). Penerapan metode VAKT berbasis parent tutoring untuk meningkatkan kemampuan membaca permulaan pada anak learning disability di sekolah inklusif. Tesis tidak dipublikasikan. Surabaya: Universitas Negeri Surabaya.

Dewi, K. (2010). "Dyslexia". Makalah dipresentasikan dalam Seminar Nasional PGSD $U P Y$. Universitas PGRI Yogyakarta.

Ghazali, M., Alias, R., Ariffin, N.A.A., \& Ayub, A. (2010). Identification of Students' Intuitive Mental Computational Strategies for 1, 2 and 3 Digits Addition and Subtraction: Pedagogical and Curricular Implications. Journal of Science and Mathematics Education in Southeast Asia, 33(1), 17-38

Hartnett, J. E. (2007). Categorisation of Mental Computation Strategies to Support Teaching and to Encourage Classroom Dialogue. In Watson, J. \& Beswick, K. Eds. Proceedings 30th Annual Conference of the Mathematics Education Research Group of Australasia - Mathematics: Essential Research, Essential Practice. Tasmania: MERGA Inc.

Herman, T. (2016). Strategi mental yang digunakan siswa sekolah dasar dalam berhitung. Diperoleh dari http://file.upi.edu/Direktori/FPMIPA/JUR._PEND._MATEMATIKA/19621011 1991011-TATANG_HERMAN/Artikel/Artikel16.pdf

Idris, R. (2017). Mengatasi kesulitan belajar dengan pendekatan psikologi kognitif. Lentera Pendidikan: Jurnal Ilmu Tarbiyah dan Keguruan, 12(2), 152172.

Istijani. (2013). Pengembangan Modul Pembelajaran Bahasa Indonesia Berbasis Multimedia untuk Anak Disleksia Pada Sekolah Dasar Inklusi. Tesis tidak dipublikasikan. Surabaya: Universitas Negeri Surabaya.

McIntosh, A. (2004a). Mental Computation: A Strategies Approach (Module 1: Introduction). Tasmania: University of Tasmania.

McIntosh, A. (2004b). Mental Computation: A Strategies Approach (Module 2: Basic Facts Addition and Subtraction)". Tasmania: University of Tasmania.

McIntosh, A. (2016). Mental Computation Of School-Aged Students: Assessment, Performance Levels And Common Errors. Diperoleh dari http://www.mai.liu.se/SMDF/madif5/papers/McIntosh.pdf 
NCTM. (2015). The number sense and operation standart of the principles and standart for school mathematics includes several concepts and skill related to beginning number sense. Diperoleh dari http://standarts.nctm.org/document/appendix/numb.html

Nirmalasari, D. N. (2013). Analisis kesulitan membaca - permulaan pada anak disleksia di SD inklusi Surabaya. Tesis tidak dipublikasikan. Surabaya: Universitas Negeri Surabaya.

Peraturan Menteri Pendidikan dan Kebudayaan RI Nomor 24 Tahun 2016 Tentang kompetensi Inti dan Kompetensi Dasar Pelajaran pada Kurikulum 2013. Jakarta: Kemdikbud RI.

Putri, S. A. (2017). Disleksia anak yang cerdas (Online). Diperoleh dari https://disleksiaanakyangcerdasblog.wordpress.com/

Rogers, A. (2016). Mental computation in the primary classroom. Diperoleh dari http://docplayer.net/34512751-Mental-computation-in-the-primaryclassroom.html

Tsao, Y. L. (2004). Exploring the Connections among Number Sense, Mental Computation Performance, and the Written Computation Performance of Elementary Preservice School Teachers. Journal of College Teaching \& Learning, 1(12), 71-90. 